\title{
Wilayah Sunda dalam Surat Kabar Sunda Era Kolonial
}

\author{
Holy R. Dhona \\ Ilmu Komunikasi Universitas Islam Indonesia \\ holy.rafika@uii.ac.id
}

\begin{abstract}
ABSTRAK
Penelitian ini adalah penelitian mengenai peranan media dalam menyebarluaskan pengetahuan wilayah Sunda modern di masyarakat Sunda awal abad 20. Mengambil surat kabar Tjahaja Pasoendan sebagai objek penelitian, penelitian ini mempertanyakan bagaimana wilayah Sunda direpresentasikan dalam surat kabar tersebut dari tahun 19131917 dan bagaimana pengaruh kolonialisme dalam wacana tersebut. Menggunakan analisis wacana Foucault, penelitian ini menemukan bahwa pengetahuan yang mendasari representasi wilayah Sunda dalam Tjahaja Pasoendan disemaikan oleh pemerintah Kolonial Belanda dimana penduduk Pulau Jawa terdiri dari dua bagian Jawa dan Sunda.
\end{abstract}

Kata Kunci: komunikasi geografi, wilayah Sunda, Tjahaja Pasoendan, kolonialisme

\begin{abstract}
This research is about the role of media in spreading knowledge of modern Sunda region in the early 2oth-century Sundanese community newspapers. Taking Tjahaja Pasoendan newspaper from the year 1913 to 1917 as the research object, this study questioned how the Sunda territory was represented in the community newspaper and how the influence of colonial knowledge/power in the discourse of Sundanese territory. Using Foucauldian discourse analysis, the study found that the representation of Sundanese territory was based on colonial government knowledge that divides the island of Java into two major parts; Sunda and Java.
\end{abstract}

Keywords : communication geography, Sundanese territory, Tjahaja Pasoendan, colonialism 


\section{PENDAHULUAN}

Ruang dan wilayah adalah produk historis. Wilayah, baik nama maupun luas beserta batasnya, tidak-lah alamiah, melainkan dicipta melalui sebuah proses. Stuart Elden (2013), dalam The Birth of Territory, mengemukakan bahwa wilayah adalah entitas yang tidak netral, melainkan dibentuk oleh banyak wacana. Elden menengarai bahwa wilayah yang kita pahami sekarang terutama diakibatkan oleh pengaturan manusia menjadi modern, utamanya dengan adanya wacana negara (state). Selain Elden, Claude Raffestin (1984; lihat juga Klauser 2012), menulis bahwa wilayah erat kaitannya dengan persoalan subjektivitas. Wilayah menurutnya adalah masalah relasi antara subjek (apakah individual atau kolektif), mediator (baik itu wilayah abstrak atau wilayah konkret) dan objek (baik itu exteriority -realitas fisik konkret di luar subjek- atau alterity -kemampuan individual untuk merubah perannya atau memproyeksikan dirinya ke dalam peran lain-). Dengan demikian, wilayah menurut Raffestin bergantung pada komunikasi.

Komunikasi dan media sebagai medium representasi berperan penting membentuk keruangan, dan, bahkan, mendefinisikan wilayah manusia. Hal itulah yang menjadi perhatian kemunculan sub-disiplin studi komunikasi, yakni Komunikasi Geografi atau Media Geografi. Falkheimer dan
Jansson ((ed.) 2006: 7) mengungkapkan bahwa relasi geografi dan komunikasi bersandar pada fakta bahwa semua bentuk komunikasi terjadi 'dalam ruang' dan semua ruang diproduksi melalui representasi melalui instrumen komunikasi. Pada pokoknya, menurut Jansson dan Falkheimer, komunikasi geografi adalah medan riset komunikasi yang berkonsentrasi pada bagaimana komunikasi memroduksi ruang-ruang manusia, dan, sebaliknya, bagaimana keruangan manusia memroduki mode atau pola komunikasi.

Lebih jauh, menurut Adams (2011), riset yang berkaitan dengan komunikasi geografi biasanya terbagi menjadi gerakan dari 4 sisi yang didefinisikan oleh dua perbedaan dimensi yang independen, yakni space/place (ruang/tempat) dan content/context (isi/konteks). Ruang dan tempat merupakan bentuk dari oposisi fundamental dalam level ontologis yang menyediakan pengetahuan dan pengalaman. Tempat (place) adalah sebuah fokus dari perhatian atau sebuah pusat dari makna sementara ruang dirasakan sebagai potensialitas, perluasan, dan gerakan. Ruang (space) memberi posisi dan orientasi pada tempat, tempat memberi karakter dan struktur pada ruang.

Hingga saat ini, komunikasi geografi atau media geografi masih merupakan lapangan riset yang jarang 
disebut di Indonesia. Padahal, medan lapangan riset ini cukup luas termasuk, misalnya, masalah pengetahuan keruangan dan kewilayahan pada apa yang kita sebut sebagai Indonesia, juga diakibatkan oleh media dan komunikasi. Gagasan itu tersirat dari temuan Benedict Anderson (1983) melalui konsep 'komunitas yang terbayang' dimana nasionalisme Indonesia adalah efek dari pertumbuhan media cetak (imprint capitalism) yang diperkenalkan oleh kolonial.

Masyarakat Hindia Belanda dan umumnya Asia Tenggara, sebelum masa kolonial, tidak mengenal wilayah sebagai identitas atau batas (boundary). Oliver Wolters (1982) meyakini pengaturan ala mandala lebih menekankan pusat (biasanya penguasa/raja) sebagai batas ketimbang wilayah. Gagasan Wolters tersebut belum tergantikan, melainkan malah dikuatkan beberapa sarjana lain. Misalnya, penelitian Thongchai Winichakul (1994:17) yang melahirkan konsep 'geo-body of nation', yakni wilayah buatan manusia yang menghasilkan efek pada orang, benda dan juga hubungannya melalui klasifikasi, komunikasi dan penguatan yang terus menerus. Nasionalisme Thailand yang menjadi objek penelitian Thongchai, pada mulanya, ditumbuhkan oleh perubahan kewilayahan pada masyarakat Thailand yang diakibatkan oleh persentuhan dengan kolonialisme. Komunikasi menjadi isu yang sangat penting dalam penelitian
Thongchai meski ia berasal dari disiplin Ilmu Politik.

Dari penjelasan di atas, fenomena komunikasi di jaman kolonial, menjadi area yang menarik dan masih perlu digarap bagi studi komunikasi geografi di Indonesia. Salah satu misi artikel ini adalah untuk mengangkat isu tentang bagaimana media dan praktik komunikasi di jaman kolonial merepresentasikan dan membentuk wilayah.

Peneliti sendiri telah meneliti bagaimana teknologi komunikasi modern turut membentuk kesadaran etnis melalui wacana pembatasan teritori Sunda pada awal abad 20 di surat kabar Papaes Nonoman, majalah milik organisasi kebangsaan Sunda yang lahir pada 1913 . Lahirnya etnis Sunda di Pulau Jawa tidaklah selalu berurusan dengan narasi Kerajaaan Padjadjaran atau Kerajaan Sunda sebagaimana diyakini sebagian besar orang, melainkan berhubungan dengan bagaimana wilayah mulai muncul menjadi batas identitas manusia di Pulau Jawa. Wilayah itu diperkenalkan oleh pengetahuan geografi modern yang turut dimunculkan oleh teknologi komunikasi modern, yakni surat kabar dan bahasa. Penentuan dialek utama Sunda atau bahasa Sunda pada awal abad 20, tidaklah hanya menentukan bahasa Sunda mana yang harus dipakai oleh orang Sunda, tetapi juga menentukan sampai pada wilayah mana bahasa tersebut akan dipergunakan. (Dhona, 2016). 
Sayangnya, penelitian yang dilakukan peneliti atas masyarakat Sunda hanya dilakukan pada satu media cetak Sunda di awal abad 20, yakni Papaes Nonoman. Oleh karena itu, tulisan ini akan mencoba melengkapi penelitian tersebut dengan mengambil objek surat kabar Sunda yang dipublikasikan di jaman yang sama, yakni Tjahaja Pasoendan.

Surat kabar Tjahaja Pasoendan merupakan surat kabar pertama berbahasa Sunda yang diproduksi oleh pribumi Sunda. Surat Kabar Tjahaja Pasoendan berbentuk majalah dan terbit dua kali dalam sebulan. Data yang dimiliki oleh Perpustakaan Nasional adalah data dari tahun 1914, 1915 dan 1917. Sementara data tahun 1913 juga 1918 dan 1919, peneliti dapatkan dari perpustakaan koleksi pribadi Kemala Atmodjo.

Tjahaja Pasoendan sendiri adalah surat kabar yang dimotori oleh pengurus atau aktivis Syarikat Islam yang berasal atau bertempat di Sunda. Meski berbahasa Sunda, Tjahaja Pasoendan rupanya jarang memuat tulisan-tulisan dengan elemen etnis Sunda yang kental karena garis politik Syarikat Islam bukan merupakan organisasi etnis, melainkan merupakan organisasi yang lebih kental dengan corak Islam. Oleh karenanya adalah menarik untuk melihat bagaimana wilayah Sunda direpresentasikan dalam majalah Tjahaja Pasoendan? Bagaimana pengetahuan yang mendasari representasi tersebut?

\section{Metode Penelitian}

Penelitian ini adalah penelitian kualitatif dan menggunakan perspektif konstruksionis dalam melihat teks (Hall. 2003). Penelitian ini didasari hipotesis bahwa representasi wilayah Sunda dalam surat kabar Tjahaya Pasoendan adalah hasil konstruksi, dan dalam hal ini konstruksi yang dimaksud adalah berkenaan dengan relasi kuasa atau dominasi pengetahuan kolonial.

Selama dekade kedua awal abad 20, terdapat empat media berbahasa Sunda. Menurut Daeng Kanduruan Ardiwinata, di surat kabar Papaes Nonoman pada 1 Oktober 1914, ada ada empat tijdschrift (surat kabar) Sunda masa itu, yakni Papaes Nonoman (terbit pada 1914), Tjahaja Pasoendan (terbit sejak Oktober 1912), Panoengtoen Kamadjoean (sejak Maret 1913) Piwoelang Kagoeroean (Ekadjati 2004:57). Dari semua surat kabar tersebut, hanya satu surat kabar yang telah diteliti bagaimana peranannya membentuk kewilayahan Sunda, yakni Papaes Nonoman. Untuk itu, penelitian ini ingin mengambil surat kabar yang lain sebagai objek penelitian dalam rangka memperhitungkan keragaman wacana kewilayahan Sunda kala itu, dan menguji kesimpulan yang telah dirumuskan pada penelitian terdahulu. Berdasarkan ketersediaan dokumentasi surat kabar yang ada, maka penelitian ini akan mengambil objek surat kabar Tjahaja 
Pasoendan. Dari surat kabar tersebut, akan dipilih teks-teks yang merepresentasikan wilayah Sunda.

Teks mengenai wilayah Sunda dalam Tjahaja Pasoendan dianalisis sebagai wacana. Teks sebagai wacana berarti meyakini ada aturan dari pernyataan atau teks. Konsentrasi dari analisis wacana adalah pada aturan yang menyebabkan teks. Wacana dalam penelitian ini diturunkan dari pengertian wacana Foucauldian, yakni "aturan-aturan dan struktur-struktur yang memproduksi ungkapan-ungkapan dan teks-teks khusus" dan bukan keadaan aktual sebuah ungkapan atau teks yang diproduksi (Mills. 1997, hal. 7). Wacana berarti 'sebuah praktik/pernyataan yang diatur' (Foucault \& Sheridan, 1972: 80). Dalam konteks penelitian, representasi wilayah Sunda dalam surat kabar Papaes Nonoman dianggap sebagai sebuah praktik yang diatur oleh sistem pengetahuan dan kuasa dalam jaman tertentu dan lokal tertentu.

Karena objek penelitian merupakan teks di masa lalu, pengumpulan data dalam penelitian ini akan bertumpu pada studi dokumen. Studi dokumen menurut Burhan Bungin (2007: 121) adalah "salah satu metode pengumpulan data yang digunakan dalam metodologi penelitian sosial untuk menelusuri data historis".

\section{PEMBAHASAN}

3.1 Volksbibliothike (Perpustakaan Daerah) sebagai Peta Wilayah

Teks Tjahaja Pasoendan yang berbicara fokus pada identitas Sunda dan wilayah Sunda sangatlah jarang. Kalah secara jumlah dari, misalnya, wacana kemajuan dan perempuan. Menurut saya, hal ini disebabkan Majalah Tjahaja Pasoendan sendiri tidak memfokuskan dirinya pada masalah etnis sebagaimana surat kabar Papaes Nonoman yang memang merupakan majalah organsiasi etnis Sunda, Paguyuban Pasundan. Namun demikian, wacana mengenai wilayah Sunda tetaplah ada dan penting.

Pada 15 Juli 1913, Tjahaja Pasoendan menerbitkan sebuah artikel yang ditulis oleh seorang murid STOVIA (The School tot Opleiding van Inlandsche Artsen atau sekolah dokter) berasal dari Sunda bernama Dajat Hidajat. Dajat Hidajat, di tahun yang sama, menjadi pemimpin bagi organisasi pelajar Sunda di STOVIA, yang kemudian dikenal sebagai Paguyuban Pasundan (Ekadjati. 2004).

Dalam teks tersebut, Dajat Hidajat menulis bagaimana menghadapi kemajuan yang sedang menggema di seluruh Hindia Belanda. Ia juga mengabarkan berdirinya perkumpulan pelajar Sunda di STOVIA yang belum lama berdiri. Di akhir tulisan, Dajat menulis sebagai berikut. 


Pasundan maju! Jangan
ketinggalan dari yang lain,
meskipun tidak jadi yang
terdepan. Tuan-tuan ingat:
Pasundan punya orang Sunda
dan oleh Orang Sunda.

Kepada Tjahaja Pasoendan saya mengucapkan selamat semoga selamanya maju dan berhasil menuntun kita orang Pasundan. Semoga jadi identitas, ciri, bendera dan kitab orang Sunda semua.

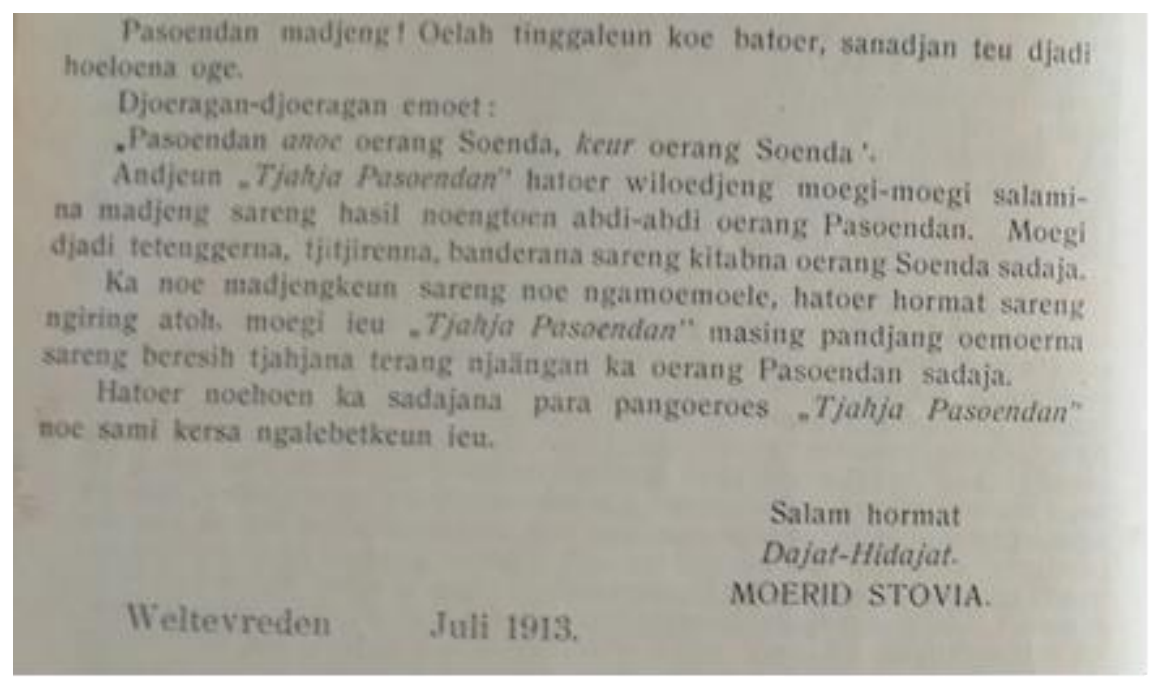

Gambar 1. Teks artikel Dajat Hidajat (Tjahaja Pasoendan. Edisi 15 Juli 1913)

Meski dalam teks tersebut tidak terdapat terminologi yang berkaitan dengan wilayah geografi Sunda, tetapi ada kesadaran Sunda sebagai sebuah bangsa, dengan batas-batas tertentu. Pada masa itu, Sunda memang tidak dikenali sebagai etnis, tetapi sebagai bangsa (Dhona, 2016). Dengan mengatakan bahwa Pasundan milik orang Sunda dan oleh orang Sunda, imaji mengenai sebuah wilayah Sunda dan didiami oleh kelompok masyarakat yang beridentitas Sunda menjadi mungkin meski sifatnya abstrak dalam arti tidak menunjuk pada material wilayah yang jelas.

Dalam teks di atas pula, batas bagi bangsa Sunda adalah pada bahasa. Dajat mengetahui bahwa surat kabar berbahasa
Sunda sebagaimana Tjahaja Pasoendan dibaca oleh orang-orang Sunda yang berbahasa Sunda. Oleh karenanya, ia hanya menyinggung masyarakat Sunda, tidak bangsa yang lain.

Wacana kewilayahan Sunda yang lain muncul dalam artikel berjudul Sadjarah Tjimaneungteung yang terbit pada tanggal 15 April 1915 yang ditulis oleh M Kartaatmadja.

Sungai Cisanggarung itu keluarnya dari pegunungan Cageur di onderdistrik Darma distrik Kadugege (Cirebon), di kepala sungai ini terdapat hutan yang besar dan penuh dengan hewan seperti monyet. Lutung dan sejenisnya, dan disitu ada pekuburan Dalem Cager. Sungai ini mengalir ke utara-timur lewat distrik Losari, disebutnya sungai 
Cilosari; yang dijadikan batas tanah Bahasa Sunda dan Bahasa Jawa

Demi Tjisanggaroeng tea kaloearna ti pagoenoengan Tjageur di onderdistrict Darma district Kadoegede (Cheribon) dina sirah ieu waloengan ngageret kakaian noe galede, sarta pinoeh koe sasatoan, kajaning monjet. Loetoeng djeung sabangsana, djeung didinja teh aja pakoeboerana Dalem Tjageur. Ieu waloengna ngotjor ngaler-ngetan ngaliwatan district Losari, diseboetna Tjilosari; ngadjadikeun wates tanah basa Soenda djeung basa Djawa.

Dalam teks di atas, Sungai Cilosari dituliskan menjadi batas dari tanah berbahasa Sunda dan tanah berbahasa Jawa, tanah orang yang berbahasa Sunda dan tanah orang yang berbahasa Jawa. Batas alam (sungai) yang ditunjuk oleh teks di atas, sebenarnya sering dirujuk oleh masyarakat pra-kolonial sebagai batas wilayah (Darmosoetopo, 2003). Teks di atas, menurut hemat peneliti, masih berkonsentrasi pada bahasa yang bersifat abstrak sebagai batas antara Jawa dan Sunda.

Wacana kewilayahan yang menarik terdapat dalam artikel yang membahas masalah Volksbibliothike atau perpustakaan daerah, misalnya artikel Volksbibliothike pada Tjahaja Pasoendan edisi 31 Oktober 1913 atau Sejarah Ngadegna Volksbibliothike (Tjahaja Pasoendan edisi 15 November 1913).
Perpustakaan daerah ini hadir, menurut penulisnya, untuk kegiatan membaca yang penting dalam rangka memajukan sebuah bangsa. Perpustakaan di Jawa bagian barat sudah ada semenjak setahun (jadi pada 1912), dan kemudian disusul di Jawa bagian tengah dan timur. Perpustakaan pertama kali diadakan di sekolah kelas 2 dan tangsi militer. Menurut keterangan penulis, bahwa bahasa dalam buku-buku perpustakaan tersebut tergantung daerah tempat perpustakaan itu berdiri.

Belum seberapa lamanya di Jawa Tengah dan jawa Timur juga sudah diadakan perpustakaan sebagaimana di Pasundan, tetapi bahasanya tentu bahasa Jawa dan Melayu, tapi belum terlalu banyak, dipilih mana tempat yang ramai saja, namun nantinya ke depan tentu ditambah secukupnya.

Tjan sabraha lilana di Djawa tengah djeung di Djawa wetan oge geus di ajaan bibliotheek tjara di pasoenda, ngan basana tangtoe basa Djawa djeung Malajoe, tapi tjan pati loba, dipilih mana tempat noe rame bae, ari engkena mah kahareup tangtoe bae ditambahan satjoekoepna (Tjahaja Pasoendan edisi 31 Oktober 1913)

Perpustakaan rakyat adalah tempat bacaan atau buku yang dalam jaman itu merupakan jembatan kemajuan. Namun jenis bahasa buku-buku yang terdapat dalam perpustakaan rakyat tersebut sangat tergantung pada lokasi 
dimana perpustakaan rakyat tersebut diadakan. Perpustakaan di Jawa Tengah dan Jawa Timur menurut teks di atas tentulah berisi buku-buku yang berbahasa Jawa dan Melayu (bahasa yang umum bagi seluruh masyarakat Hindia Belanda kala itu). Teks dalam Tjahaja Pasoendan tersebut mengandaikan relasi antara subjek pembicara bahasa dengan identitas wilayah. Jawa Barat adalah tempat bagi orang yang berbahasa Sunda sementara Jawa Tengah dan Timur adalah tempat bagi orang yang berbahasa Jawa.

Sementara itu, artikel Sejarah Ngadegna Volksbibliothike (Tjahaja Pasoendan edisi 15 November 1913) menceritakan mengenai sejarah pendirian perpustakaan

Sudah menjadi pemikiran pemerintah, bagus sekali jika di distrik-distrik atau di desadesa diadakan perpustakaan rakyat supaya kita semua bisa mudah meminjam ragam buku yang berguna, agar dapat menambah kepandaian. Untuk itu, Kanjeng Gupernemen sudah mengadakan satu komisi yang disebut Commissie voor de volkslectuur ya ini yang diberi kuasa menyediakan bukubuku untuk perpustakaan rakyat.

Sekarang meski buku-buku perpustakaan rakat belum cukup juga, namun cukup pantas perpustakan dibuka (di Pasundan sudah satu tahun, di Jawa 2-3 bulan)

Geus kamanah koe Pamarentah Agoeung, hade pisan lamoen di districtdistrict atawa di desa-desa diajaan volksbibliotheek soepaja maranehanana bisa gampang ngindjeum roeparoepa boekoe anoe berguna, pikoen nambahan kapinteranana njaeta soepaja tinekanan samaksoed tadi tea.

Tina kitoena Kangdjeng Goepernement geus ngajakeun hidji commissie disebutna Commissie voor de volkslectuur nja ieu noe dikawasakeun, pikeun njadiakeun boekoe-boekoe baris Volksbibliotheek teh.

Ajeuna sanadjan boekoeboekoe pikeun volksbibliotheek tea tatjan tjoekoep oge, tapi koe timbangan commissie geus meudjeuhna bibliotheek dibuka (di Pasoendan geus sataoen, di Djawa kakara 2-3 boelan)

Dalam kalimat di atas, juga didapati bahwa kewilayahan Sunda yang diimajinasikan adalah kewilayahan berdasar bahasa, dimana disitu didirikan perpustakaan oleh pemerintah berdasarkan kebijakan Commissie voor de volkslectuur. Artinya, kewilayahan yang disepakati oleh masyarakat Sunda merupakan produk dari pemerintah Hindia Belanda.

Model wacana kewilayahan dalam teks mengenai Perpustakaan Daerah ini, menurut peneliti, berbeda dengan model wacana kewilayahan Sunda yang berbasis bahasa/pengguna bahasa. Dalam teks mengenai perpustakaan daerah khusus orang Sunda, identitas yang tadinya bersandar pada pemakai/orang (bahwa seseorang menjadi Sunda karena bahasa yang ia hasilkan) kini dialihkan pada 
'wilayah'. Perbedaan bahasa dimaterialkan dalam bentuk buku cetak dan buku cetak dipusatkan pada realitas perpustakaan yang dibangun di atas sebuah wilayah, sebuah materi yang padat.

Pada konteks ini, gagasan Benedict Anderson bahwa pertumbuhan nasionalisme terjadi karena pertumbuhan kapitalisme cetak adalah benar. Nasionalisme beriringan dengan sifat patriotisme atau rasa cinta tanah air, yang harus punya objek wilayah yang jelas. Buku-buku cetak yang berpusat di perpustakaan adalah representasi dari kejelasan wilayah. Jika bahasa disematkan pada tubuh manusia, maka manusia adalah makhluk yang berpindah. Sementara oleh pemerintah kolonial Belanda, bahasa tidak hanya disematkan pada tubuh manusia, melainkan pada buku cetak dan akhirnya buku cetak dipusatkan pada perpustakaan yang berrelasi dengan tanah/wilayah.

\subsection{Sunda adalah Jawa Bagian}

\section{Barat}

Teks yang juga penting mengenai kewilayahan Sunda muncul pada tahun 1918, tepatnya pada Tjahaja Pasoendan edisi 15 Maret 1918. Pada edisi ini, Tjahaja Pasoendan menerbitkan kembali tulisan yang dimuat di Surat Kabar Padjadjaran yang berjudul Robahan Paparentahan.

Artikel tersebut menyoal perubahan pemerintahan di Hindia Belanda kala itu. Artikel itu mengutip pula kebijakan desentralisasi di Hindia Belanda yang sebenarnya mulai diberlakukan pada 1903. Karena Hindia terdiri dari banyak bangsa, budaya dan ragam adat istiadat, maka pemerintah Belanda hendak menuntun pada terbentuknya sebuah federasi.

Karena di Hindia banyak rupa bangsa yang tidak sama bahasanya, adat istiadatnya, sejarahnya, sebisa-bisanya sekarang setiap bangsa berdiri sendiri tapi tetap satu. Jadi oleh pemerintah mau dituntun untuk menjadi federasi

Cocok sekali paham SI dan Insulinde digunakan, sebab memajukan bangsa lebih cepat, jika dasarnya kemajuan bangsa sendiri dan mengingat pada keadaan bangsa ketimbang dipaksa dijadikan satu sebagaimana cara yang dimaui Insulinde (atau juga SI)

Koe lantaran di Hindia loba roepa-roepa bangsa noe teu saroea basana, adat istiadatna, sadjarahna, sabisa-bisa ajeuna oenggal bangsa sina ngadeg sorangan, tapi koedoe ngahiji. Djadi koe pamarentah rek ditoeungton kana federatie.

Tjotjog pisan haloean SI djeung Insulinde teh dipake, sabab ngamadjoekeun bangsa leuwih gantjang, moen dadasarna kamadjoean sorangan djeung ngingetkeun kana kaajaan bangsa ti batang djeung dipaksa didjieun hidji bangsa tjara kahajang Insulinde (atawa SI) (Tjahaja Pasoendan Edisi 15 Maret 1918) 
Artikel tersebut meneruskan bahwa tanah Jawa akan dibagi menjadi tiga propinsi, yakni: 1) Pasundan (Banten, betawi, Cirebon dan Priangan); 2) Kajawen (batasnya dari Timur Surabaya dan Kediri); 3) Bangwetan (Soerabaya, Kediri, Pasuruan, Besuki dan Madura). Lebih jauh, artikel tersebut mengingatkan bahwa jika harus mengingat adat istiadat, keadaan dan kemajuannya, bangsa pulau Jawa harusnya dibagi menjadi 4 bagian yaitu; 1) Jawa barat atau pasundan (banten, Betawi, Cirebon, dan Priangan); 2) Semarang (karesidenan Banyumas, Kedu, Pekalongan dan Semarang); 3) Surabaya (Kediri, Rembang, Madiun dan Surabaya); 4) Jawa Timur atau Madura (Pasuruan, Besuki dan Madura). Ini berarti bahwa usulan menjadi empat bangsa tersebut hanya mempermasalahkan Madura yang dianggap penulis mempunyai kebudayaan yang berbeda dengan wilayah Surabaya. Sisi menarik lainnya artikel tersebut adalah bagaimana wilayah Sunda tetap konsisten terdiri empat daerah, yakni Banten, Betawi, Cirebon dan Priangan. Dengan demikian, keempat daerah tersebut sudah dianggap mempunyai kebudayaan yang sama dari bahasa, adat dan lain sebagainya.

Teks artikel tersebut juga dibubuhi tabel sensus penduduk yang selesai dilaksanakan pada tahun 1917.

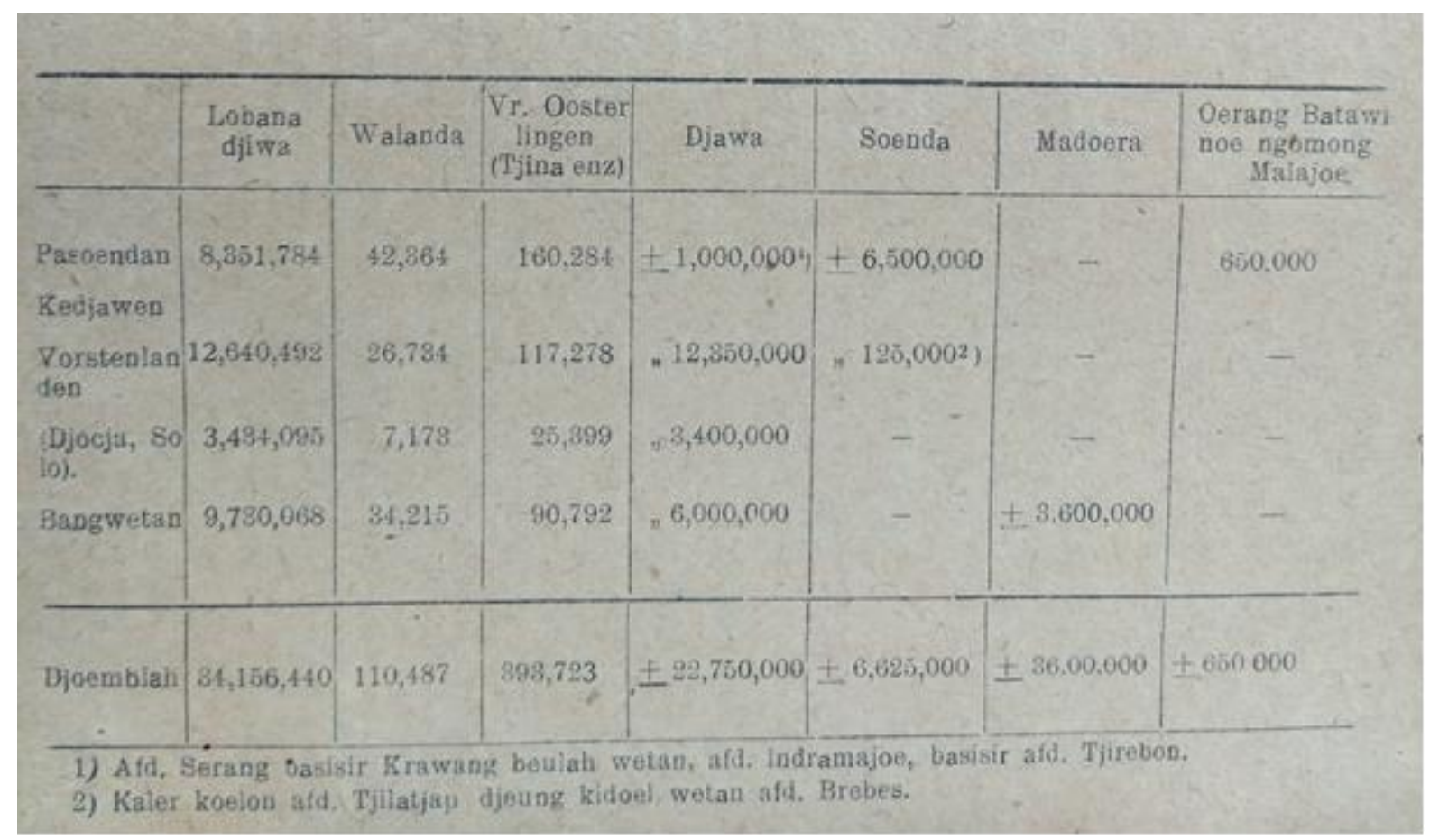

Gambar 2. Tabel Sensus Penduduk/Cacah Jiwa Pulau Jawa 1917 (Tjahaja Pasoendan. Edisi Maret 1918) 
Dari keseluruhan teks yang dianalisis, batas wilayah Sunda pada mulanya bertumpu pada penggunaan bahasa, yang berarti bahwa ia bertumpu pada komunitas orang dan bukan wilayah. Sebenarnya, bahasa sudah dikenali oleh masyarakat pribumi sebagai salah satu boundary dalam interaksi mereka dengan bangsa lain di masa pra-kolonial. Namun, identitas kolektif, yang kala itu dikenali sebagai 'bangsa', tidaklah padat, melainkan cair. Hal ini seturut dengan argumen Andaya dimana identitas etnis di Asia Tenggara sebelum masa kolonial adalah cair (Andaya, 2008: 238). Namun, bahasa tampak makin menjadi batas identitas pribumi dengan adanya materialisasi yang bersandar pada wilayah, yakni buku, sekolah dan perpustakaan oleh pemerintah kolonial Belanda. Artinya benar argumen Benedict Anderson (1983) bahwa perpustakaan dan buku yang dikhususkan pada komunitas tertentu itu membentuk komunitas yang diimajinasikan.

Materialisasi batas identitas ke dalam bentuk wilayah menjadi penting karena menurut Thongchai (1994) simplifikasi pembentukan kebangsaan hanya pada elemen pembentuknya (misalnya bahasa) akan mengabaikan pendefinisian batas dari identitas tersebut. Simplifikasi ini akan mengacuhkan sampai sejauh mana sebuah bahasa atau tradisi tidak lagi diperhitungkan sebagai bagian dari sebuah nation. Dengan wilayah, kita menjadi tahu bagaimana konstruksi sebuah elemen, dimana identitas dimulai dan berakhir. Meskipun demikian, konstruksi identitas kebangsaan yang diinisiasi pemerintah Hindia Belanda tidaklah dilihat sebagai ancaman atau sebagai bentuk dominasi, karena perpustakaan adalah tempat bahan bacaan atau buku, sementara buku adalah instrumen yang membuat masyarakat pribumi menjadi 'maju'. Pada saat itu, wacana kemajuan diterjemahkan oleh banyak penulis di Hindia Belanda sebagai 'sekolah' atau 'buku-buku'. Kemajuan adalah juga peniruan terhadap Belanda sebab Belanda atau Eropa dianggap sebagai pusat kemajuan (Dhona: 2015). Pendirian perpustakaan tersebut akhirnya memang tampak 'alamiah' dan bukan sebuah upaya rekayasa sosial pemerintah kolonial atas pribumi.

Tatkala kebijakan desentralisasi hendak diberlakukan sebagaimana kita lihat dari teks berita Tjahaja Pasoendan berjudul Robahan Paparentahan pada 1918. Pada akhirnya, materialisasi identitas kultural (bahasa) menjadi 'buku' 'sekolah', 'perpustakaan' tersebut membentuk sebuah wilayah geografi, terutama yang terjadi pada wilayah Sunda. Meskipun dalam tabel sensus penduduk di tahun 1917 wilayah Sunda juga dihuni oleh pribumi yang berbahasa Betawi yang dituliskan sebagai "orang Betawi yang bicara melayu”, tetapi Sunda secara konsisten berbeda dari Jawa dalam konteks wilayah. Dalam hal ini, Pemerintah kolonial Belanda, terus 
menganggap Sunda sebagai satu kesatuan wilayah Jawa bagian Barat yang berbeda dengan Jawa di bagian timur. Hal ini menerangkan imaji kolonial dimana pulau Jawa hanya dibagi menjadi dua bagian wilayah bahasa; Sunda dan Jawa. Tidak ada bangsa lain selain kedua bangsa tersebut di atas tanah Jawa ketika itu. Sebagaimana dikemukakan Dhona (2016), imaji tentang pembagian dua bangsa, yang dikenali sebagai etnis, di Pulau Jawa, berasal dari pembagian pulau Jawa menjadi dua oleh kolonial yang dimulai oleh pelaut Portugis dan diteruskan oleh pemerintah Inggris.

Pembagian wilayah Sunda-Jawa dapat dibaca di Decada yang ditulis Jono de Barros juga Diogo Do Couto, dua orang penulis Portugis ketika Portugis hendak mengadakan perjanjian dengan kerajaan Sunda tahun 1522. Barros, seperti yang dikutip oleh Raffles, pun membagi Jawa menjadi dua pulau yang dibatasi sungai Losari atau Cilosari.

Portugis, yang telah menduduki Malaka pada 1511, datang ke Pulau Jawa untuk membela kerajaan Sunda yang sedang dikepung Banten dan Cirebon, dua wilayah di Jawa bagian Barat yang telah berubah menjadi kesultanan Islam. Oleh karenanya, Portugis harus membatasi apa yang mereka namakan sebagai Sunda dari 'yang lain'. Guillot, yang menuliskan soal Banten, menyatakan bahwa para penyusun sejarah Portugis, terlebih-lebih Barros, ingin menuliskan perkara yang dihadapinya sebagai sebuah episode dalam pertempuran sengit yang disodorkan orang Islam kepada Portugis (lihat Guillot, 2008: 272). Pendapat ini tampaknya memperkuat gagasan Graaf dan Pigeaud (1985: 74) bahwa penulis Jawa tidak pernah mementingkan perspektif agama dalam menulis.

"Ternyata bagi para penulis Jawa pada abad XVII dan abad sesudahnya, perbedaan agama (antara kafir dan Islam) tidak begitu penting dibanding dengan kesesuaian dalam pemerintahan. Padahal para penulis ini orang Islam, malahan mungkin banyak di antara mereka termasuk 'golongan orang alim'

Lebih jauh, Barros membaca Pulau Jawa sebagai "wilayah-wilayah agama", untuk itu ia kemudian menggunakan istilah-istilah seperti 'Mahomedan' atau 'Moors'. Kategori yang timbul dari jejak 'semangat perang Salib' Barros ini yang kemudian digunakan Raffles. Namun tidak dengan gugus pandang yang sama dengan Barros dan Couto. Term 'Mahomedan' memang masih dipakai di History of Java, tetapi ia tidak mendapat porsi yang banyak di tangan Raffles ketimbang apa yang dilakukan penulis Portugis. Raffles tidak membangun agama sebagai dasar batas Sunda dan Jawa, ia mengubah 'batas agama' menjadi 'batas budaya' dengan memperluas wacana perbedaan Sunda dan Jawa dengan bahasa dan kebudayaan. 


\section{Kesimpulan}

Dalam teks surat kabar Tjahaja Pasoendan yang dipublikasikan oleh aktivis Serikat Islam Jawa Barat, wacana mengenai wilayah Sunda memang sedikit ketimbang dalam teks surat kabar Papaes Nonoman. Hal itu dikarenakan orientasi Sarikat Islam yang tidak kedaerahan ketimbang Papaes Nonoman yang memang menyediakan dirinya sebagai organ bangsa Sunda. Namun dalam pewacanaan kewilayahan Sunda, tidak ada perbedaan pengetahuan yang mendasarinya, pengetahuan yang mendasari representasi wilayah Sunda disemaikan oleh pemerintah Kolonial Belanda dimana penduduk Pulau Jawa terdiri dari Jawa dan Sunda.

Wilayah Sunda diwacanakan sebagai wilayah bagi penutur bahasa Sunda. Selain itu, wilayah Sunda juga mendapatkan bentuk material dalam wujud perpustakaan daerah berdasarkan kebijakan Commissie voor de volkslectuur. Artinya kewilayahan yang disepakati oleh masyarakat Sunda merupakan produk dari pemerintah Hindia Belanda. Wacana kewilayahan dimaterialisasikan melalui wacana Perpustakaan Daerah. Identitas wilayah Sunda yang abstrak dan disandarkan pada pemakai/orang (bahwa seseorang menjadi Sunda karena bahasa yang ia hasilkan) kini dialihkan pada 'wilayah'. Perbedaan bahasa dimaterialkan dalam bentuk buku cetak dan buku cetak dipusatkan pada realitas perpustakaan yang dibangun di atas sebuah wilayah, sebuah materi yang padat, dimana sebuah identitas mempunyai batas yang jelas.

$$
\text { Hingga pada akhirnya, }
$$
materialisasi identitas kultural (bahasa) menjadi 'buku' 'sekolah', 'perpustakaan' tersebut membentuk sebuah wilayah geografi, terutama yang terjadi pada 'wilayah Sunda' pada 1917. Dalam tabel sensus penduduk di tahun 1917 wilayah Sunda juga dihuni oleh pribumi yang berbahasa Betawi yang dituliskan sebagai "orang Betawi yang bicara melayu", bahasa tidak terlalu penting ketimbang wilayah. 


\section{Daftar Pustaka}

Adams, P. (January 01, 2011). A taxonomy for communication geography. Progress in Human Geography, 35, 1, 3757 .

Andaya, L. Y. (2008). Leaves of the same tree: Trade and ethnicity in the Straits of Melaka. Honolulu: University of Hawai'i Press

Anderson, B. R. O. G. (1983). Imagined communities: Reflections on the origin and spread of nationalism. London: Verso.

Atja \& Danasasmita, Saleh 1981.Sanghyang Siksakanda $\mathrm{Ng}$ Karesian; Naskah Sunda Kuno Tahun 1518 Masehi. Atja

Burhan, Bungin, 2007. Penelitian Kualitatif: Komunikasi, Ekonomi, Kebijakan Publik, Dan Ilmu Sosial Lainnya, Edisi pertama, Cetakan ke-2, Jakarta: Kencana

Darmosoetopo, Riboet. 2003. Sima dan Bangunan Keagamaan di Jawa Abad IX-X TU. Jogjakarta: Prana Pena

Dhona, Holy. R (2015). Wacana Kemadjoean di Kelompok Etnis Sunda Awal Abad 20. Informasi UNY, 45(2), 171181.

Modern Communication Technology in The Invention of The Geo-body of Sundanese. Proceedings of the 2nd World Conference on Media and Mass Communication, Vol. 1, 2016, pp. 27-33
Ekadjati, Edi S (2004) Kebangkitan Kembali Orang Sunda: Kasus Paguyuban Pasundan 19131918. Bandung: Kiblat Buku Utama

Elden, S. (2013). The birth of territory. Chicago ; London : The University of Chicago Press

Foucault, M., Sheridan, A., \& Foucault, M. (1972). The archaeology of knowledge. New York: Pantheon Books.

Falkheimer, J., \& Jansson, A. (2006). Geographies of communication: The spatial turn in media studies. Go teborg: Nordicom

Guillot, Claude. 2008. Banten: Sejarah dan Peradaban Abad X-XVII. Jakarta: Kepustakaan Populer Gramedia

Graaf, H. J., \& Pigeaud, T. G. T. (1985). Kerajaan-kerajaan Islam pertama di Jawa: Kajian sejarah politik abad ke-15 dan ke-16. Jakarta: Grafitipers.

Klauser F R, 2012, "Thinking through territoriality: introducing Claude Raffestin to Anglophone sociospatial theory". Environment and Planning D: Society and Space 30(1) $106-120$.

Mills, Sara. 1997. Discourse. London\&Newyork. Routledge.

Moriyama, Mikihiro. (2003). Semangat Baru : Kolonialisme, Budaya Cetak, dan Kesusastraan Sunda Abad 19. Jakarta. Kepustakaan Populer Gramedia 
Raffestin, C (1984) Territoriality: A Reflection of the Discrepancies Between the Organization of Space and Individual Liberty. International Political Science Review 1984 5: 139 Sage Publication

Raffles, T. S. (1830). The History of Java: 2 Volume. London: Black.
Thongchai, W. (1994). Siam mapped: $A$ history of the geo-body of a nation. Honolulu: University of Hawaii Press.

Wolters, O. W. (1982). History, culture, and region in Southeast Asian perspectives. Singapore: Institute of Southeast Asian Studies. 
Jurnal Komunikasi, Volume 11, Nomor 1, Oktober 2016 